\begin{tabular}{l|l}
$\mathbf{m}$ & south \\
asia
\end{tabular}

samaj multidisciplinary

'i.'

journal
South Asia Multidisciplinary Academic Journal

$12 \mid 2015$

On Names in South Asia: Iteration, (Im)propriety and Dissimulation

\title{
On the Im/Propriety of Brand Names
}

William Mazzarella

\section{(2) OpenEdition \\ Journals}

Electronic version

URL: http://journals.openedition.org/samaj/3986

DOI: 10.4000/samaj.3986

ISSN: 1960-6060

Publisher

Association pour la recherche sur l'Asie du Sud (ARAS)

Electronic reference

William Mazzarella, "On the Im/Propriety of Brand Names », South Asia Multidisciplinary Academic Journal [Online], 12 | 2015, Online since 21 September 2015, connection on 19 April 2019. URL : http:// journals.openedition.org/samaj/3986 ; DOI : 10.4000/samaj.3986

This text was automatically generated on 19 April 2019.

\section{(c) (i) (3) $\Theta$}

This work is licensed under a Creative Commons Attribution-NonCommercial-NoDerivatives 4.0 International License. 


\title{
On the Im/Propriety of Brand Names
}

\author{
William Mazzarella
}

\section{AUTHOR'S NOTE}

Deep thanks to Veena Das and Jacob Copeman for inviting me to participate in the panel that led to this collection. Their consideration, forbearance, and wonderful commentaries allowed me to skate onto thin ice with some self-consciousness but with little embarrassment. Three anonymous reviewers for SAMAJ helpfully and tolerantly put things in perspective. Special gratitude is due to Costas Nakassis, whose engagement with a rather eccentric draft version of the paper was both generous and challenging in the most exemplary way.

\section{Proprius}

1 What kind of name is a brand name? A proper name, evidently, but of a curious kind. A brand name, like other proper names, must refer only to itself. At the same time, it has to be capacious enough to encompass within itself a sometimes-bewildering range of product extensions, both in the present and in the future. How should we understand the way in which a brand name grounds this play of identity and difference, of coherence and incoherence, of past, present, and future? Is there something about proper names as such that allows this to happen? Conversely, is there something about brand names that prompts us to rethink what we think we know about proper names?

The Norwegian writer Karl-Ove Knausgård (2013) observes that a proper name is the one thing in fiction that resists being fictionalized. And of course this is also true of that particular kind of fiction that we call ethnography. When I turned my PhD thesis into the book that was published as Shoveling Smoke (2003), my decision to anonymize the names of the brands in the section based on my fieldwork in a Mumbai advertising agency meant that I was unable to include some of the material that I want to discuss in this essay, since 
this little bit of material was all about the names. Now that fifteen years or so have passed since I wrote that book, I feel that I can speak those names more freely. People have moved on, brand names have changed. The world that was tied to and animated by those names has dissolved. But of course it is still a judgment call. ${ }^{1}$

3 Names contain and organize, as it were, the life of their times. We cannot, in the last instance, exert full control over the resonances and potentialities of any name, including our own. And yet consumer capitalism as we know it today could not exist were it not that we are legally permitted to own and sell brand names, as well as their associated graphic properties. If brand names are proper names, then their proprius is double, referring at once to a property of mine (a distinctive characteristic) and my property (legal ownership). Many would argue that there is something inherently suspect about corporate claims to exert sovereign control over brand names, given that brands only have value insofar as we invest our collective imaginative labour and our responsiveness, our mimetic addressability, in them. What kind of 'primitive accumulation' is branding? By what right and by what means can a corporation so to speak enclose a piece of the collective mimetic archive (Mazzarella forthcoming) under its name? As Rosemary Coombe writes, trademarks and brand names attempt to channel 'the cultural energy of mimesis into the form of the signature' and to 'appropriate it under the proper name' (1996: 207).

4 Like other kinds of property, names can be stolen. Corporations police their brand properties rigorously, punishing unauthorized appropriations and defacements. Private individuals receive alerts about identity theft. Indeed, stealing a name is an ancient form of magic. But if names can be stolen like any other kind of property, then perhaps it is still only names that can be taken in vain. Taken in vain: the phrase suggests at once the possibility of transgression against a sacred name and the vanity of thinking that a name can, in any conclusive sense, be 'taken' at all. For as we shall see, brand names clarify the extent to which names can only perform their remarkable magic by being at once less and more than they seem.

\section{Strong but wrong}

5 My story begins with a name that sounded strong but wrong. ${ }^{2}$ One of the big clients of the ad agency in which I was conducting my fieldwork in 1997-98 was a cellphone provider operating under the brand name BPL mobile. BPL mobile was a division of a larger Indian consumer electronics company called BPL Group. BPL Group, whose corporate slogan at that time was 'Believe in the Best,' had established itself in the field of household appliances during the 1980s, when new consumer technologies were becoming available to the Indian middle classes through joint ventures with foreign producers. BPL had forged a solid, reliable reputation as an Indian face for world-class products, bringing their customers 'the best' of what was available elsewhere at a time when foreign companies were not allowed to market their products under their own brand names in India. With liberalization, not only were an increasing number of those foreign brands now directly available in Indian stores (although generally at high prices) but, as a result, BPL's image as a solid, reliable conduit of quality was also beginning to look unsexy: always there, adequate-in the Hindi phrase, chalta hai (good enough/it'll do).

6 Certainly my interlocutors in the ad agency felt that BPL Group's homely image was holding the BPL mobile division back in its attempts to conjure the kind of hi-tech, global, 
exciting atmosphere that was in those days considered requisite for the cellphone category, which was still fairly new and small in India. The agency, in other words, had a major client on their hands that was operating in a product category that required a certain 'voice,' but doing so under a brand name that markedly lacked that voice. So the agency had moved decisively to, as it were, re-voice their client's name, causing a splash for BPL mobile by launching a new product, an all-in-one ready-to-go pack containing a phone, a SIM card, and a charger, a product that the agency, after much back and forth, had given a new name: Mobile On the Spot. And the splash had started, as it must, with the client; the BPL mobile executives had been suitably dazzled and adrenalized by the agency's presentation.

7 But now cooler heads were prevailing, and BPL mobile was worrying that Mobile On the Spot's flashy vitality was 'fighting with' the BPL Group 'motherbrand.' Was there a risk that pouring money into advertising for the new product might turn Mobile On the Spot into a quasi-autonomous 'sub-brand' that would then, as the client so vividly put it, turn around and 'cannibalize' the motherbrand? During the agency's initial creative process, Mobile On the Spot had not, in fact, been the first name to stick; earlier contenders had included Velocity and Contact. One of the reasons the ad agency manager preferred Mobile On the Spot was that it seemed more like a product descriptor than a potential (sub-)brand name. Compared to Contact, he said, it had a 'retail feel'; it seemed most directly to express the plug-and-play promise of the new product.

8 There were other complications as well. A few months earlier BPL mobile had launched yet another product, a freestanding SIM card under the name InstaCard. Following the splashy launch of Mobile On the Spot, stocks of InstaCards were now languishing unsold in warehouses. One senior BPL mobile executive had proposed that this overstock now be repackaged in Mobile On the Spot look-alike packaging under the name BPL Mobile On the Spot InstaCard. Learning of this, the agency team objected that such a cumbersome concatenation of names would be inelegant and, moreover-this argument always worked with the client-divert attention from the motherbrand. Conceding the point, the BPL mobile executive then suggested that Mobile On the Spot be renamed in such a way as to reconcile it with InstaCard: why not kill two birds with one stone by calling the new product InstaMobile? 'Obviously we said no,' the copywriter told me the following day. 'This would create the same problems as with Contact-you're putting another sub-brand out there.'

\section{Detachable vessels}

In a mass-mediated society-that is to say, in a society premised on stranger-socialitythe reputation-bearing function of names becomes all the more important since each of us is, on a daily basis, expected to trust strangers with our money. Under conditions of mass mediation, brand names are, as Constantine Nakassis $(2012,2013)$ points out, eminently useful kinds of detachable semiotic vessels. They can circulate far and wide and yet always point back to a (putatively) stable brand essence. At the same time, through deftly managed brand extensions, a brand name should also, up to a point, be able to incorporate new products: Virgin begins as a record label and subsequently turns into not only a record store but also an airline, a publishing house, a line of hotels, a mobile phone service and so on. Branding, then, aspires to play a delicate game with singularity and multiplicity. A brand name is at once a mark of identity and a space of 
differentiation. Synchronically, at any given moment, it must be both organizing and capacious. Diachronically, over time, it must both remain loyal to its particular histories and open up to its potential futures.

When BPL mobile called a meeting with the agency at BPL corporate headquarters in central Mumbai to discuss the problem of 'synergizing the retail segment,' the agency team knew it was in a delicate situation. Certainly it wanted and needed to defend its baby, Mobile On the Spot. It knew that it was facing a client who was struggling to reconcile its lingering seduction by Mobile On the Spot with the quite different tonalities of its corporate brand. But the agency also had both short-term tactical and long-term strategic ambitions. Right now, it only handled BPL's cellphone division. Short term, it made sense for the agency to encourage BPL mobile to create and advertise as many new products as possible. But if the agency could come across not only as the backer of Mobile On the Spot but also as a potential custodian of the larger corporate brand, then there might well be more and bigger business to be won from BPL in the future. And for that to happen, the BPL brand name had to stay just as much front and center as that of Mobile On the Spot or any other product. Effectively the agency team had to argue that, contrary to all palpable signs, there was no conflict between the BPL motherbrand and Mobile On the Spot-that they were, in some deep sense, 'the same.' And yet, in order to justify the existence of Mobile On the Spot as an entity deserving its own advertising rupees despite the risk of motherbrand cannibalization, the agency team also had to argue that there was a tactical difference between them.

11 The question was: did the name Mobile On the Spot designate a clearly distinct object? And if it did, then what kind of object was it? Ostensibly, this might seem a silly question. After all, there was a product and that product was, apparently, doing reasonably well. At the same time, Mobile On the Spot didn't actually offer customers any new components; it merely recombined existing products-a SIM card, a phone, and a charger-in a more convenient way. In the agency-client meeting, the agency team struggled to clarify exactly what sort of thing their baby was, and thus the grounds on which its separate name might be established. Ambiguity reigned at every turn. Having launched Mobile On the Spot, the agency team noted, BPL mobile was bringing its customers a service, but not in the same sense as the service provision on which their brand was based. Yes, Mobile On the Spot was a product, but not in any really distinctive way, since each of its components was already available separately. Nor was the package aspect of Mobile On the Spot quite convincing enough. As a BPL mobile executive demanded, on the verge of desperation: 'How can we justify pumping all this advertising money into launching what threatens to become a new sub-brand when it's not even its own product?! Certainly it's a package, but then so is everything else with packaging!'

In its early meetings with BPL mobile, the need to define the distinct object-ness of Mobile On the Spot had not arisen, because, conscious of their client's worry about brand integrity, the ad agency team had stressed that it was nothing more than a product descriptor and that customers would inevitably ask for the product by the client's brand name: BPL mobile. In this way, the agency team had managed both to reassure the lead client executive about its respect for the integrity of the BPL brand and excite him with the racy new look that it had devised for Mobile On the Spot ('very techno-fechno,' as one member of the agency team had characterized it). But now this same client executive was concerned that if BPL mobile was going to commit substantial funds to advertising Mobile On the Spot, then it had better be future-proof: it should be able to accommodate future 
variations and extensions for different kinds of customers and occasions. But if it was that extendable, then was it not threatening to become a separate sub-brand rather than merely a product descriptor? Was it not, in short, threatening to become a proper name?

\section{The symptom of the name}

13 The very idea of a 'sub-brand' suggests an anxiety: a brand that is not supposed to be a brand, a non-brand that is brand-like. ${ }^{3}$ It hints at the excess that always threatens to disrupt the self-identity of the brand name qua proper name, to destabilize its quality of, to use Saul Kripke's (1980) famous phrase, rigid designation. Proper names, according to Kripke, are rigid designators because they designate the same thing in all possible worlds. Rigid designation is less a fixed characteristic of proper names than a potentially profitable aspiration toward semiotic stability, more or less coherently achieved. Brand names help us to see that this stability is not so much a relation of reference (a name referring to an object) as what early anthropologists of religion and magic, for example Lucien Lévy-Bruhl, called participation. Elsewhere I have written at length against the pejorative associations that continue to cloud our reception of these ideas (Mazzarella forthcoming).

For my purposes here, we need only remind ourselves of Emile Durkheim's (1995) classic argument about totemism. Durkheim argued that the power of the totemic sign, which we may take as a kind of proper name, does not depend on it referring to the animals or plants from which it takes its name, or to the human individuals that identify with (belong to) a particular totem. Rather there is a necessary relation of common substance, a relation of participation, between all of them, marked and coordinated by the totemic sign qua-to use Kripke's term anachronistically-rigid designator. In a similar way, brand name variants (BPL Group, BPL mobile and so on) participate in, and thus also designate, the commodity instances of the brand (various products, some with their own names: Mobile On the Spot, InstaCard etc., as well as the various graphic and sensory properties associated with the brand).

Participation involves a curious mixture of singularity and relation. At one level, the proper name refers only to itself; it is necessarily self-evident. In our constructivist times, names still carry an untimely aura of the thing-in-itself; some names are thought to be 'truer' than others (Pina-Cabral 2010). True names may often be protected by 'shield' names (Das, this collection). One offers up a shield name for generalized circulation, thus keeping the intimate authenticity of the true name safe from the malevolence it might attract. At another level, then, names must circulate, must 'talk to' and articulate with other names. Theodor Adorno (2006) once observed that a truly proper name would have property only in itself; it would be self-identical to the point of utter non-identity. It would be useless in the best sense-that is to say, it would be entirely unavailable for any human purpose. That would be its frustration and its delight: expression without exchange.

Such an ideal of a name resistant to all trafficking, to all truck and barter, arises from the threat of injury implicit in the circulation of names as tokens of value and identification in a currency over which we may have little control. My name opens me to the world, makes me vulnerable to hostile magic. Judith Butler (1997) and others point out that there is always a kind of violence in naming-the violence of interpellation, of 
subjectivation and subjection; indeed, Butler notes, the very phrase 'name-calling' refers in English to insulting someone. But in order to function socially, my proper name must constantly risk commonness-or, as brand managers anxiously put it, 'genericide.' If the intimate properness of my name opens me to the world, then its tendency toward commonness also opens the world to me. Names are, in this sense, hinges. Modern governmentality is only possible because names translate singularity into relation and vice versa. As Alain Badiou puts it: 'The name is what allows singularity to assert its worth beyond itself' (2007: 104; see also Vom Bruck and Bodenhorn 2006). My signature allows the law to recognize and record me in my singularity, but it also inserts me, bureaucratically, into an order of equivalence where I am one among others. My name can be a passport to my rights as a citizen, but it will also pin me down as an object of surveillance and tie me to my guilt.

The 'truth' or 'authenticity' of a name is at stake in its circulation. This is why namespersonal names as well as brand names-are such powerful and delicate vehicles of reputation. The public disintegration of a reputation can be shocking and painful, not simply because the implosion of a name brings about what is arrestingly called a 'loss of face,' but also because, as Aditya Bharadwaj suggestively notes in his contribution to this collection, the public coming apart of a name often involves an unpredictable activation of its constituent elements, now disarticulated from the previously rigid structure of the solid name. 'Names and naming,' Bharadwaj writes, 'by their very nature consecrate through a process of inscription and encryption.' Inscription and encryption: the very same organizing principle (inscription) that allows the name to designate also, as it were, secretes a virtual or 'unconscious' dimension of the name (encryption) with a life of its own that is nevertheless constitutive of the actual life of the name.

We are all familiar with dramatic moments of shaming, scandals in which the name of an individual or a corporation melt down, 'become dirt.' But the power and vulnerability embedded in this double relation of inscription and encryption is not just relevant to sudden moments of breakdown or collapse. It is, rather, a permanent feature of the vitality and vulnerability of names in their everyday circulation. Slavoj Žižek (2012) observes that the name of even a common noun is at once external to the features of the thing it describes and yet somehow also condenses and embodies its irreducible, unenumerable intimate essence. The name, to invoke a Lacanian phrase, is 'what is in the named object more than itself.' For Žižek, a name is symptomatic, then, both in the sense that it is quintessentially characteristic of what it names, and in the sense that there is something excessive in it, something that obtrudes or insists beyond the (apparently) simple work of reference. This constitutive excess of the name is, as we shall see, both key to its fascination and a constant threat to its integrity. As a delicate hinge between singularity and relation, the proprius of the name must be ritually managed, whether by explicitly legal conventions that define how and when we may lay claim to names or by observances and prohibitions that performatively reproduce their auratic singularity.

\section{Regimentation and proliferation}

The semiotic regimentation of a brand extends to its human custodians. I recall, for instance, an occasion during my dissertation fieldwork in Mumbai when, arriving with a group of ad executives at an event sponsored by one of the agency's clients, I was instructed, sotto voce, by one of my companions to get rid of a can of Coke I had been 
carrying, even though the event we were attending was not sponsored by one of Coke's competitors. The unstated assumption was that because the agency serviced the account of Canada Dry (then owned by Cadbury Schweppes), its executives-and, by further extension, incidental associates like me-could not be seen in a professional context to be associated with the Coke brand name.

And yet even the most basic brand publicity involves something more and something less than a conscientiously regimented semiotic space. As Nakassis shows, branded publicity is inherently (self-)citational. And each branded citation (each appearance of the brand name in advertising and on products) performatively proliferates what Nakassis calls 'brand surfeits'-the 'more than' of a brand, unruly potentials that both power the vital aura of the brand and defeat any attempts definitively to discipline its meaning. Perhaps one might say that brand surfeits are the actualized forms taken by the brand name's inevitable symptomatic eruptions. But do these surfeit eruptions trouble or ground the proprius of the name?

21 Nakassis' examples of brand surfeits include counterfeits, brand parodies, fakes and so on -surfeit actualizations that, as it were, 'speak back' to the official brand, sometimes in its 'own' name, sometimes in satirical impersonation of its voice. Thinking with Jacques Derrida (1995), we might propose that when brands 'give' their names to their rightful progeny, the goods that are legally authorized to carry their name, they also become narcissistically vulnerable to acts of separation, violations of the name in the name of the brand. But even here, as Nakassis shows, the relation between brand success and brand failure is ambiguous. For all that brand managers worry about unauthorized appropriations, for all that corporations jealously and expensively police the circulation of their brands, the proliferation of counterfeits may divert some customers away from the authorized product while at the same time heightening the prestige of 'the real thing.' For brand names, too, imitation may be the sincerest form of flattery. If brand surfeits in a sense belong to the brand name, then the real challenge to brand management may not be, as it were, brand identity theft so much as the difficulty of insisting on the externality and otherness (i.e. the non-participation) of the fake vis-à-vis the original.

The difficulty of drawing a clean ontological boundary between the brand name original and the spinoffs that its surfeits may permit is not merely a function of its circulation. Or rather one might say that a brand name is, as it were, always already 'precirculated': its surfeits are not just the sparks that the brand name throws off as it touches down in various social contexts. They may also be imagined as the activations of potentialsencryptions, to use Bharadwaj's term-that live in a shared sensuous-mimetic context and that necessarily shadow the inscription of the name on whose wings they take flight.

The relation of participation that grounds the brand name as a rigid designator tends to come with its own myths of origin about a constitutive and deliberate moment of naming. Kripke calls it baptism: an act that combines a gesture of indication with the giving of a name; his example is pointing to a star and saying 'That is to be Alpha Centauri.' This is also how branding is popularly imagined, as if, in some leisurely strategic panopticon, advertising and marketing professionals simply find the name and brand positioning that best 'fits' a fully formed product. It is an image of virgin illumination, innocent of history. The reality is a great deal messier. Brand names generally arise quite literally in medias res , in the middle of things, in a hectic competitive field, through a process that is part improvisatory divination, part bricolage. This is why we must, I think, read Kripke's 
baptism scenario as mythical and ideological, a story that is retroactively told in order to lend an authorizing origin and stability to the unsteady social career of a name.

Perhaps the complementary opposite of Kripke's baptism, in which a mute object passively receives its name and thus, as it were, comes alive, is Adorno's evocation of a living world that already contains its own names, challenging us to achieve a mode of sensuous attunement in which we would be able to receive them. Tellingly, for Adorno, the bearers of true names address us wordlessly: 'In existing without any purpose recognizable to men, animals hold out, as if for expression, their own names, utterly impossible to exchange' (Adorno 2006: 228). That Adorno then proceeds to observe: 'This makes [animals] so beloved of children, their contemplation so blissful' (ibid) leads one to suspect that he is invoking that spontaneously transformative mimetic faculty that Walter Benjamin (1999) found undimmed in children. If animals hold out their own names' to us, then we must apprehend them aesthetically rather than by means of referential labels. To those who can listen, then, language-less animals, so often brutally subjected to the names humans have given them, speak their true names.

For Adorno, of course, brand names embodied the very opposite of such sensuously available truth. Brand names involved a kind of prostitution of language, a promiscuous hollowing-out of the name, ubiquity without content, sentiment without life, a puppet performance of authenticity; in short, an absolute instrumentalization of the name in the service of a rationalized marketing apparatus. As with so much in Adorno's critique of the administered society and the culture industry, one gets the sense of a radical fantasy of perfected law, of rationalization without remainder: a world in which rigid designation had been fully and permanently achieved. But there is no reason to suppose that brand names are any less vulnerable to the symptomatic instability of surfeits than any other kind of name. If anything-and I want to read Adorno against himself here-Adorno's invocation of an aesthetic attunement to the names that, as it were, already dwell in the world helps us to understand the tactile and tactical improvisations of brand-work.

\section{Divination}

To imagine that the name Mobile On the Spot referred primarily to the physical package containing a cellphone, a SIM card, and a charger would be to miss the point. Of course the physical package became one of the commodity instances of the name, but the vitality, the texture, the voice of the name-the 'substance' in which all of its elements participated -existed at first only in the most virtual way: as a kind of affective potentiality awaiting concrete actualization.

The first step toward actualizing that substance was, one could say, a kind of exploratory divination. The agency team was painfully aware of the assertiveness with which BPL mobile's competitor in Mumbai (at that time, each urban cellphone market in India had two providers), MaxTouch, had been able to seize control of a desirably dynamic semiotic space. The agency wanted to conjure a similar (but of course also different) magic for BPL mobile. The challenge was to 'lighten up' some of the BPL motherbrand's perceived stolidity while not confusing BPL mobile's offerings with the brand elements-colours, fonts, graphic signatures-of MaxTouch.

The copywriters and art directors on the account spent a great deal of time, together and alone, feeling their way through textual and visual elements that might capture and 
convey the identity-space of what would become Mobile On the Spot, which at first had neither a name nor a solid description. Gradually, as ideas were batted back and forth, both the conceptual contour of the space-'survival in a harsh urban environment'-and the name that would designate that conceptual contour began to crystallize. Typically, the process involved the creative team flipping through stock image catalogs or advertising compendia from Europe and the United States, testing their hunches and impulses against existing institutions, honing their intuitions toward something that felt right when articulated. It wasn't that the team was looking for ideas to copy. Rather, it was absorbed in a kind of generative contemplation-one might say, a state of mimetic receptivity-in which the client's brief and the team members' own aesthetic intuitions were allowed to rub up against an existing set of images so as to release surfeits that might then be translated into something that, retroactively, would appear all long to have been the perfect name for and articulation of an object that, for now, existed only virtually.

Nor did this mimetic divination end once the product parameters-name, graphic look, packaging etc.- had been decided and were being presented to the client. Except for during the most tightly scripted parts of these presentations, the agency team's interaction with the client team similarly involved a great deal of improvisatory surfeitconjuring and tea leaf-reading. All kinds of associations and connotations would be evoked, taken up, and dropped. Like good fortune tellers, the members of the agency team were constantly monitoring the client team for the slightest cues, using the latter's facial expressions and incipient utterances as cues for on-the-fly adjustments to and translations of a series of advertising inputs that, all the while, had to seem like they were expressing a consistent idea. While one could easily dismiss such behaviour as commercially motivated sycophancy, I think it would be more useful to acknowledge its mobile and highly sensitive divinatory aspect. Rather than having baptized a fully-formed object, the agency and its client had found a name for an approximate affect, and were now collectively engaged in 'reading' each other in such a way as to produce a set of image and text objects that the name might designate in a way that would feel at once pleasurable and necessary.

In a sense both agency and client teams were like participants at a séance, mediums actualizing the virtual potentialities of a shared mimetic archive. The personified spirit invoked in the séance was 'the consumer'-a putatively objective anchor for what might otherwise seem an entirely arbitrary process of invention. Both agency and client executives would summon 'the consumer' at key moments of uncertainty, with a rhetorical air of finality that was generally not supported by any external evidence. Very often, as we shall see in the following vignette, 'the consumer' served, as it were, to bring third-person social 'grounding' or 'perspective' to hunches that either the client or the agency team might speculatively and 'subjectively' offer in the self-referential indexical first person. At the same time, in these meetings, the 'I' of the speaker would often slide in and out of direct identification with the imagined or reported 'I' of 'the consumer.' Either way, these conversations involved a delicate dance between an invocation of external third-person authority and charismatic-performative first-person attempts to make this external authority align with-participate in-the object that was emerging in the room (cf Urban 1987). ${ }^{4}$ The objective 'reality' of two entities and their mutual alignment was at stake here: that of the branded object and that of the consuming subject. 
BPL mobile had, as we have already seen, woken up with a hangover from its initial intoxication with Mobile On the Spot, anxious about the same vital potential that had initially seemed so attractive, but which now seemed to threaten the emergence of a surfeit with a life/name of its own: a sub-brand. Consequently, one of the lead BPL mobile executive's first gambits in the post-launch meeting with the agency was to insist that any customer, walking into a retail outlet, was going to ask for the brand name that they already knew, and which differentiated BPL mobile, along a chain of equivalence, from its competitor. So why risk muddying the waters by promoting another name, Mobile On the Spot? As the conversation gradually grew heated, the BPL mobile executive fell back-for greater emphasis but also appealing across the table to a presumptively shared habituson a first-person situation: 'Let's say I go into a shop and I want to buy a Walkman, na?' Clicking his tongue impatiently, the agency manager interrupted him right away: 'Bad example, yaar. It's become generic.' Abandoning analogies, the BPL mobile executive then resorted to a simple first-person claim to common sense: 'What I'm saying is, I'm not going to ask for 'BPL Mobile On the Spot'-it's too much of a mouthful.' Frustrated, the agency manager retorted, almost recklessly: 'Yes you will!'

At this point, holding up his hand with an air of Apollonian panopsis, an account executive from the agency team intervened by trying to shift the conversation, via an invocation of the ever-available 'consumer,' back to the objective feel of the third person -without any evidentiary support other than, again, a tone of calm common sense: 'Hold on. Whether it's becoming a sub-brand for you and me, it's not for the consumer.' The BPL mobile executive, sticking doggedly to the performative promise of his first person extrapolation, insisted: 'I'm not going to go in and ask for 'BPL Mobile On the Spot.' I'll go in and ask for BPL mobile.' The agency manager, having recovered his composure, was alive to the psychological importance of allowing his client to assume a first-person perspective in any conversation involving his brand. That way, the client would feel like he 'owned' the potentials and pitfalls that any vision of the future might suggest. Accordingly, the agency manager stuck with second person address as a way of trying to shift his client's first-person anxiety toward a more expansive horizon: 'Yes today you'll ask for BPL mobile,' he began by reassuring his client, before smoothly transitioning into a vision of brand extensions to come, each requiring their own designators albeit not their own brands: 'But tomorrow? Tomorrow you might have two, three different cards. You might have the pastel phones especially for the ladies. You might have the hep phone only with local calls for the teens. I don't know what-all you'll have. But what are you going to ask for then?' The BPL mobile executive acknowledged the point, but, to collective howls of protest from the agency team, proceeded to deduce that by that logic the product should be advertised as 'BPL Mobile Mobile On the Spot.'

\section{I, the brand}

Marketing is generally imagined as the art/science that facilitates encounters between consumer-subjects and branded objects. In the previous section, I showed how attempts to settle both the content and the coherence of the branded object were inextricable from attempts both to invoke and-by means of theatrical and projective uses of the first person (Urban 1987) - to enact and inhabit the consumer-subject who might desire it.

But what about the branded object as subject? Is the brand name not, after all, the name in which the corporation addresses its publics and thus a kind of prosthetic self? As I note in 
Shoveling Smoke, advertising executives routinely identify quite intimately with the brands for whom they may be long-term custodians, priding themselves on understanding the voice in which the brand 'speaks' and the kinds of inputs it 'needs.' Agencies sometimes inculcate such brand identification in their employees by running games in which executives and creatives are expected to act in the name of the brand, identifying, from a range of options and with as little hesitation as possible, words, images, and situations that characterize 'their' brand.

Marketing theory, of course, routinely metaphorizes brands as people. Textbooks refer to brand personalities, brands are imagined as speaking in certain kinds of voices, the brand-consumer relation is explicated and cultivated by analogy to interpersonal relations, and focus groups are commonly asked to imagine the brands with which they interact as human types. But it is as if we encounter an uneasy crossing point when we move from the third to the first person. As long as the game sticks to the third person (referring to the brand as 'it' or even, tongue in cheek, 'he' or 'she'), we may playfully invoke accusations of commodity fetishism while all the time resting assured that we are dealing in 'mere' metaphor. Things feel stickier, though, when the 'I' of the human speaker blends with the 'I' of the brand. But why should they? After all, as Greg Urban notes, "the "I" of discourse is not only an actual in-the-world subject, indexically referred to by means of the first person form. The discourse "I" can also be any being or entity, imaginary or not, capable of being reported as a speaker' (Urban 1987:29). What boundary does first person speech in the name of the brand trouble?

The theory of commodity fetishism would suggest that to speak of the ' $\mathrm{I}$ ' of the brand is to commit a fatal act of ontological confusion: attributing life and subjectivity to inanimate things, and thus facilitating our own complementary reification. By this logic, a brand name, as Adorno might have said, lends a sham appearance of interiority to something that hovers between a speaking object and an artificial person. We may of course give a proper name to an inanimate object. Indeed, Kripke's ideal-typical baptism scenario proceeds in the third person: 'that is to be Alpha Centauri.' Its success does not require any attentiveness or agreement on the part of Alpha Centauri. But personal names are, apparently, quite different in this regard (assuming they are not given posthumously).

Jean-Claude Milner (n.d., 2010) notes, developing an Althusserian-Lacanian line of thought, that our human emergence as singular and unique speaking beings requires a first-person assumption of our names, that is to say the ability to connect our names with the act of saying 'I.' But this first-person assumption of a name depends, in turn, on a temporally prior interpellating address in the second person: 'by imposing a proper name on the infant in the second person, one constitutes it as a speaking being and therefore as being capable of speaking in the first person' (Milner 2010: 16). But the crucial point is that this process of interpellation requires a retroactive reversal from the standpoint of the speaking subject: 'the initial moment in time is the second person, but the foundational moment for the subject is in the first person' (ibid). Here, then, is another perspective on the uncanny combination of lack and excess that seems to dwell at the heart of names: in order for me to assume first-person proprietorship over my name-in order for me to say ' $\mathrm{I}$ ' in its name-I must repress the priority of another time, a time when my name was addressed to 'me' but it was not yet mine, a time when it did not yet ground the subjective unity of 'I' and 'me.' We should not regard the first-person assumption of our names as a once-and-for-all process, achieved and settled in childhood. 
Shoring up the propriety of our names against and within their constitutive other time is a lifelong project. Here, too, brand name-work is instructive.

As I describe in detail in Shoveling Smoke (and as any viewer of the AMC television series Mad Men will know), an advertising agency team sells an idea to its client by means of a carefully calibrated, part-improvised performance in which the purpose is not simply to convince the client that the proposed advertising solution is a good idea but also, more profoundly, to interpellate the members of the client team via their tendency/desire to identify with the corporate 'I' of the brand name they represent and, in a sense, embody. In Lacanian terms, the agency seeks to move the client, without interruption, from an imaginary identification with the visual-affective contours of the proposed advertising materials to a symbolic lamination of the product image onto the already-interlaced relation between the 'I' of the client and the first-person name of its brand.

As we have already seen, the process involves a fascinating oscillation between third, second, and first-person deployments of the brand name. As a third-person entity the brand, like the putative 'consumer,' generally already exists. It has a history that can be invoked, whether as inspiration or as challenge. It has accreted a reputation that can be documented and explored through market research, whose findings can be strategically mobilized when necessary and dismissed when distracting. And the ' $\mathrm{I}$ ' of the client is, as noted, already identified with the voice of the brand. Consequently, it becomes easy for the agency team to address the client-as-the-brand in the second person while-and this is the interesting part-at the same time sliding in and out of third and first person invocations of the brand.

In this exercise at one level the client is the brand and is acknowledged as the one who rightfully speaks in its name. And yet what the agency is simultaneously doing while presenting its ideas is conjuring the brand as an entity whose true essence resides elsewhere, an essence that, through the agency's discerning work, can, in a more focused form, be channeled back into the client's first person speech as the brand. In order to achieve this, the agency team will shift back and forth between third person expressions of the brand ('BPL mobile is...') and first person enactments of the brand voice/attitude/ idea ('I'm the kind of guy who...'). This becomes possible because the implicit assumption is that the brand name does not so much refer to an existing place, object, or person as organize a space in which particular potentials can be desirably and impressively actualized.

41 Veena Das remarks, in her contribution to the present collection, that when it comes to names, 'The issue is not that of reference-how does a proper name refer-but rather of reaching into the open texture of the name through which a range of affects can be condensed and presented all at once without need of further description.' The work of branding renders particularly acute the tension between the two aspects of Das' reflection on names: the sense of an active potentiation of affects ('reaching into the open texture of the name') and the sense of self-evidence ('without need of further description'). When names circulate, as they must, something unpredictable comes alive -there is, in Nakassis' terms, a proliferation of surfeits-and yet, paradoxically, this proliferation can only happen through the protocols and rituals through which we try to manage the integrity of names as rigid designators. 


\section{A clearing appears}

\section{perhaps say that the inscription of subjectivity that allows us to speak in our 'own' names} simultaneously encrypts, within that named subjectivity, the unconscious of the name. The symptomatic eruptions of this unconscious of the name-'what is in the name more than itself-take rather different forms when a name is functioning well than when it fails. To the successful name, the eruptions of its encrypted side add that quality of authentically numinous aura, 'a phenomenon of distance, however close it may be' (Benjamin 1968: 222). The constitutive 'other histories' of the name-the ones that are foreclosed in order for it to speak in the first person-remain as a kind of depth echo, adding gravitas but not disrupting the name's successful (re-)inscription. The collapsing name or the name that never quite wants to come together is, by contrast, suddenly and very obviously riddled by surfeits that it cannot master, and that stand in the way of its plausible first person articulation.

This was the crisis faced by the advertising agency team in the wake of Mobile On the Spot's attention-grabbing debut. Having devised a name for its client, and initially generated the kind of client euphoria that every agency lives for, all involved were now looking at a name that seemed, vis-à-vis the all-important BPL motherbrand, all surfeit and no identity. Formally, the problem seemed to be one of irreconcilable semiotics and thus non-participation in the name. In its own defense, the agency team certainly felt that the problem arose in large part from the incoherence of its client's desire: a desire to speak through a new name in the name of the old name. After several exhausting iterations of the debate as to whether Mobile On the Spot had any reason to exist as a separate product name, whether it was turning into a sub-brand, whether 'the consumer' was going to ask for it or not and so on, the lead BPL mobile executive called a break and left the conference room. The agency team retreated into a tactical huddle.

One of the account executives sensed more trouble ahead. Recently, BPL mobile had started toying with the idea of rebranding its retail outlets as Mobile Spots. Leaning in, the account executive whispered urgently to his boss, the agency manager, regarding the client's new plan: 'Achcha, he's coming from two directions here. You're the only one who can get him out. He's going to complain that there's a lack of consistency between [the previously launched freestanding SIM card] InstaCard and Mobile On the Spot when it comes to the retail outlets. Only one of these is about spots!' The remark had the intended effect on the agency manager, who blurted indignantly: 'But come on, yaar! We can't be in a situation where our branding efforts are determined by the name of the retail outlets!'

At this moment, the BPL mobile executive returned to the room. The agency manager was still fired up and, in a brilliant maneuver, turned the scenario around so as to convince the client of the inherent absurdity of insisting that the names of all aspects of the operation be coordinated: 'Look at an example from your own organization,' he rallied. 'BPL Galleries. What do they sell? The whole range of products. Doesn't mean that I have to call the products "Gallery." In his turn suitably horrified, the BPL executive protested: 'No, no-that's nothing more than a coincidence!'

46 The stratagem was as absurd as it was inspired. By stretching the name-participation outward to such a degree of encompassment that it began to look preposterous (a world in which every single aspect of BPL's activities had to bear the same single name), the

South Asia Multidisciplinary Academic Journal, 12 | 2015 
agency team was able to relieve the pressure on the smaller semiotic zone where nameparticipation had until that moment seemed crucial. Some room for maneuver had been cleared, even while nothing about the long-term strategic problem had been solved. Tactically, the splintering surfeits of the two names at issue-BPL mobile and Mobile On the Spot-now allowed a different aspect to dawn (see Das, this collection).

The agency-client meeting was taking place a month or so before Diwali, the festival of light, and traditionally the beginning of the Hindu wedding season. The agency account executive saw his chance to realign sense and sensibility and grabbed it. Was not Mobile On the Spot the perfect happy/sad wedding gift from parents to their departing daughter, accentuating both her tentative independence and her indelible connection to her natal household? And did not such a positioning resonate perfectly with the benign if slightly boring affect of the BPL motherbrand as the long-standing quality custodian of Indian consumer interests? Never mind that a mobile phone was, at best, an ambiguous gift (who was, in the end, going to pay for the calls?) If only for a season, the agency had managed to conjure a plausible participation under their client's name, and everyone seated around the table could breathe a sigh of relief and begin looking forward to shooting an exceptionally emotive TV commercial.

\section{Conclusion: im/proprieties}

Wherein lies, then, the im/propriety of brand names? Perhaps first and most of all in the way that the work of branding so clearly discloses the im/propriety of proper names in general. The power of names would seem, as I have been suggesting throughout this paper, to rest on something rather more ambiguous than simple referential 'fit.' And yet of course the feeling that a name 'fits' what it names is an important part of the everyday phenomenology of names. It allows names to seem 'right' in both a propositional and a moral sense. This aspiration to the fitting name, but also the sense of fit as substantial participation rather than reference, comes across loud and clear in Sean Dowdy's remark, elsewhere in this collection, regarding normative expectations in Mayong: 'Recall that personal names and their embodied subjects are meant to become the same thing over time' (original emphasis).

The peculiarity of brand names is not that they work by means of a more or less successful sense of participation-this is true, I would suggest, of all proper names. Brand names, however, have to do more: they must continuously solicit the active and interested engagement of those whose attention they seek. Any of us might desire acknowledgment and recognition of our names. But brand names solicit our participation in their names while at the same time asserting sovereign control over their names. In Shoveling Smoke, I extended Annette Weiner's (1992) work on inalienable objects by suggesting that we think of this as the 'keeping-while-giving' of the brand. My argument then was that branding forges an inalienable singularity out of the alienable proliferation of commodities: it allows the corporation to 'keep' the brand while 'giving' the commodity.

But in the larger project I was also trying to show-as I have in this paper-that branding 'strategy' cannot be quite as immaculate as its boosters as well as its critics tend to imagine. I am not saying that branding must bend to real consumer desire-that would presume, as marketing theory must, that consumer desire is knowable prior to its actualization vis-à-vis specific products and brands (Mazzarella forthcoming). Rather, 
brands invite us to join a collective game of potentiation, a game of activating brand surfeits. We all do the work, but corporations and advertising agencies then do their best to harness and narrativize that work around a name over which they can assert legal ownership and sovereign custody. But as we have seen here, owning a name is quite a different matter from speaking coherently in a name.

51 I have also suggested in this paper that we need to think beyond the conventional commodity fetishism argument, according to which the im/propriety of brand names has to do with their illegitimate anthropomorphism, their pretense at first person subjectivity. Behind the 'artificial I' of the brand lies, we like to think, another, supposedly 'real' puppet-master 'I': the 'I' of the corporation, the voice of capital. This 'I' is also, of course, a legal fiction, and serves, on dubious grounds, to grant the agents of capital the prerogatives and protections of personhood. But having acknowledged that, we are then faced with the question of what kind of 'real' personhood is presumed to attach to human names, to 'actual' persons? Here too, the im/propriety of proper names does its ambiguous work.

Tellingly, the idea that the brand-self designated by the brand name is malleably artificial (by implied contrast to the real selves designated by real names) is just as central to ideology-critical takes on consumer capitalism as it is to marketing theory. One might say that the apparent contingency and artificiality of brand names serves as an alibi for the implied necessity and stability of personal names. Having decided that brand names are essentially ventriloquists' dummies, media through which other agents 'throw their voices,' we can then continue to believe that there are self-grounding subjects with real names and real interests on either side of the brand curtain. By being paradigmatically artificial, brand names help to underwrite the proprius of proper names, including those corporate proper names that are granted the legal authority of persons.

\section{BIBLIOGRAPHY}

Adorno, Theodor (2006 [1951]) Minima Moralia: Reflections on a Damaged Life, New York: Verso.

Althusser, Louis (2001 [1970]) 'Ideology and Ideological State Apparatus (Notes Towards an Investigation)', in Lenin and Philosophy and Other Essays, New York: Monthly Review Press, pp. 85126.

Badiou, Alain (2007 [2005]) The Century, Cambridge: Polity Press.

Benjamin, Walter (1999 [1933]) 'On the Mimetic Faculty', in Michael Jennings (ed.), Walter Benjamin: Selected Writings, Volume 2, Cambridge, MA: Harvard University Press, pp. 720-27.

Benjamin, Walter (1968 [1936]) ‘The Work of Art in the Age of Mechanical Reproduction', in Illuminations, New York: Schocken, pp. 217-51.

Butler, Judith (1997) Excitable Speech: A Politics of the Performative, New York: Routledge.

Coombe, Rosemary (1996) 'Embodied Trademarks: Mimesis and Alterity on American Commercial Frontiers', Cultural Anthropology 11(2), pp. 202-24. 
Derrida, Jacques (1995) On the Name, Stanford, CA: Stanford University Press.

Durkheim, Emile (1995 [1912]) The Elementary Forms of Religious Life, New York: Free Press.

Kripke, Saul (1980 [1972]) Naming and Necessity, Cambridge, MA: Harvard University Press.

Mazzarella, William (2003) Shoveling Smoke: Advertising and Globalization in Contemporary India, Durham, NC: Duke University Press.

Mazzarella, William (forthcoming) The Mana of Mass Publicity: Anthropology Lost and Found.

Milner, Jean-Claude (n.d.) 'Remarks on the Name Jew and the Universal' [Online], URL: http:// mcpress.media-commons.org/postmedieval_middleages_holocaust/jean-claude-milner-remarkson-the-name-jew-and-the-universal-translated-by-robert-s-kawashima/ [accessed December 29, 2014].

Milner, Jean-Claude; Banfield, Ann; Heller-Roazen, Daniel (2010) 'Interview with Jean-Claude Milner', Journal of the Jan van Eyck Circle for Lacanian Ideology Critique, 3, pp. 4-21.

Nakassis, Constantine (2012) ‘Brand, Citationality, Performativity', American Anthropologist 114(4), pp. 624-38.

Nakassis, Constantine (2013) 'Brands and their Surfeits', Cultural Anthropology 28(1), pp. 111-26.

Urban, Greg (1987) ‘The “I” of Discourse', Working Papers and Proceedings of the Center for Psychosocial Studies, Chicago, 10: pp. 27-51.

Vom Bruck, Gabriele; Bodenhorn, Barbara (eds.) (2006) The Anthropology of Names and Naming, Cambridge: Cambridge University Press.

Weiner, Annette (1992) Inalienable Possessions: The Paradox of Keeping-While-Giving, Berkeley, CA: University of California Press.

Žižek, Slavoj (2012) Less Than Nothing: Hegel and the Shadow of Dialectical Materialism, New York: Verso.

\section{NOTES}

1. The world that sustains the power of particular names may dissolve, but it never quite dies. There was no explicit or written agreement, when I did my dissertation fieldwork, about what I was or was not allowed to do with names in my writing. At the time of writing up, I improvised a series of decisions that felt reasonable. Broadly, if informants were speaking to me on the record, for example in a formal interview situation, I would quote them and the brands they discussed by their real names. Conversely, I felt that much of what transpired inside the advertising agency where I did my fieldwork took place, as it were, backstage and should therefore be granted the protection of pseudonyms or generic names: 'the agency,' 'the account executive,' and so on. (I must confess to a certain enjoyment in dreaming up some of the brand pseudonyms. BPL, for instance, originally stood for British Physical Laboratories. 'My' BPL, consequently, became EMW -which in my mind stood for English Mechanical Workshop. Certainly these are acts of baptism in themselves-perhaps more so than anything that took place in the 'real world' situations I describe). In writing the present paper I have revealed only the real names of the brand and product at issue-BPL and Mobile On the Spot-on the principle that so much has changed in the Indian marketplace since I wrote Shoveling Smoke, including some of the brand names, that disclosing these names will not offend anyone. In any case, those familiar with the world that I discuss here and in my first book would be able to deduce what brands I was writing about and, if they are industry insiders, perhaps also which people served as my informant protagonists. This 
is an inevitable side effect of working in the mass publicity business. I would only add that the generic terms that I use for my informants in discussing these materials are not only meant as anonymizing devices; they are also supposed to highlight the structural rather than the personal dimensions of my informants' work.

2. Some of the elements in this story appear under other names in Shoveling Smoke.

3. Thanks to Costas Nakassis for this formulation.

4. Greg Urban's (1987) discussion of 'anaphoric,' 'de-quotative,' 'theatrical' and 'projective' uses of the first person pronoun has been extremely clarifying for me in making sense of the supple ways in which, in agency-client meetings, invocations of the first person could have, as it were, both first-person and third-person effects. My analysis departs from Urban's, however, in wanting to stress that these first person usages go both ways. On the one hand, as Urban emphasizes, they serve to align the speaker with a more or less 'fixed' impression of an impersonal cultural code, a way in which things 'are done' and 'are said.' On the other hand, I want to suggest, this 'culture'-whatever its actual formally elaborated narrative forms-is perhaps less like a code than like a virtual matrix. As such, it is not just that, for example, the 'theatrical ' $\mathrm{I}$ " aligns the speaker with a set of more or less rigid cultural expectations-what Urban (36) glosses as 'the weight of tradition.' It also provides a charismatic-performative opportunity to actualize the virtual potentials of the cultural matrix (what I would call the mimetic archive) differently-all the while lending it the appearance of pre-existing authority.

\section{ABSTRACTS}

This paper asks what kind of modifications we might have to make to our conventional understandings of proper names to accommodate the im/propriety of brand names. On the basis of ethnographic research on a naming crisis at a Mumbai advertising agency, I suggest that the classic anthropological notion of 'participation' (as opposed to reference) allows us to consider the play between baptism and the mimetic activation of virtual potentials that characterizes the public life of brand names. I argue for moving beyond the distinction between 'artificial' and 'real' proper names sustained by the theory of commodity fetishism, and propose instead that the supposed artificiality of brand identities has come to operate as an alibi for the unsteady authenticity of personal identities.

\section{INDEX}

Keywords: brand names, proper names, reference, participation, mimesis

\section{AUTHOR}

\section{WILLIAM MAZZARELLA}

Professor, University of Chicago 